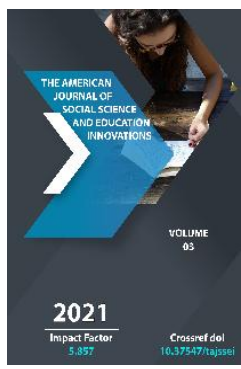

\title{
Linguistic Features Of Latin And Greek Synonymous Morphemes In The Lexical System Of The French Language (Based On Medical Texts)
}

Shakhnoza Esonovna Abraeva

Teacher, Department Of “Uzbek And Foreign Languages”, Tashkent Medical Academy, Uzbekistan

\section{ABSTRACT}

This article discusses the use of medical terminology, which includes Latin and Greek terms and morphemes. Because Latin and Greek terms are becoming a major part of medical terminology. The article also states that the main function of medical terms is to express a scientific concept in one sense. Latin-Greek morphemes play an important role in the formation of medical lexicon. In addition to the most common methods of term formation, there are also some methods, the results of which are abbreviations, homonyms, synonyms, eponyms, and so on. To understand the meaning of these medical terms, we are required to become familiar with their morphology.

\section{KEYWORDS}

Medical terminology, morpheme, morphology, Latin-Greek, lexicon, synonymy, word formation, neologism, medicine, cardiology.

\section{INTRODUCTION}

The most important modern sciences effectively use elements of classical languages in their terminology. The problem of learning lexical units from classical languages to French and other languages has been and remains relevant in linguistics. 
Due to the acceleration of the flow of information and the emergence of new lexical units in the vocabulary of the language, problems related to the formation of neologisms, analysis of assimilations, their structure and the study of semantic information are the subject of constant study.

At first glance, morphemes, synonyms, and word-formation rules seem not new to everyone. However, the analysis of synonymous elements dating back to Latin and ancient Greek, their laws of speech, and the hidden possibilities of word formation in French deserve special attention. Because such a problem is little studied in linguistics. The incarnation of lexical units of classical languages in the French language system is so great that their study is often carried out in the material of small language systems.

Based on the analysis of a particular material, the medical language possesses the greatest collection of elements of classical languages in various sub-languages. Therefore, in our scientific experience, medical texts (medicine, therapy, cardiology) are drawn against the background of widely used lexicon as an object of study. Medical topics turned out to be the most appropriate object for such research.

From the time French was formed to the present day, assimilations from Latin and Greek have not stopped enriching it, French is full of elements of ancient Greek and Latin more than other languages due to its traditions and word-formation character. French does not accept elements of classical languages as other derivatives.
In our time, there is no modern science that uses Latin and ancient Greek to the same extent as medicine for defining new concepts, for their own special dictionaries. The completeness of the medical dictionary with the morphemes of the Greek and Latin languages is so high that their study is often carried out on the basis of materials of medical terms and texts. This is facilitated by the fact that scientists in many fields of medicine in many countries understand each other by having a single anatomical nomenclature in Latin (PNA - Parisiensa nomina anatomica) adopted in 1955 at the VI International Federal Congress in Paris and an international nomenclature in histology approved in Leningrad in 1970. The main source of pharmaceutical, anatomical, and clinical terminology serves as a set of clear and stable elements of classical languages that have been successfully used in the formation of so-called "internationalisms".

According to the historical development of the composition of the French dictionary, ancient science left in it the same meaningful elements of Latin and ancient Greek. For example, cut (i) - and derm (o) -, circon- and péri-, post- and méta-, quadr (i) - and tétr (a) and so on. These morphemes have already become "international", without which no system can bypass both general and terminological subsystems of European languages, so they require constant study.

Some of the elements being analyzed turned out to be ambiguous. For example, the Greek words pneúmōn (pneumon) "lung" and pneúma (pneuma) - "air" form the morpheme pneum (o) in French, which is the result of simplification in a foreign language. Many French terms are incorrectly formed using 
these elements; they do not meet normative linguistic requirements. A. Kostitch rightly points out that the use of pneumoconiose, pneumographie, pneumomalacie, pneumomycose, pneumopathie, pneumopexie, pneumotomie, pneumectomie terms should be avoided or replaced by pneumonoconiose, pneumonographie, pneumonomalacie, pneumonomycose, pneumonopathie, pneumonotomie, pneumonectomie, pneumonopexie terms. Since the rhino-morpheme in the above words represents the "lung" in any way, these words were also analyzed.

\section{CONCLUSION}

Each modern science effectively uses elements of classical languages in its terminology. As scientific discoveries in various fields of human knowledge become inevitable, the emergence of neologisms in terminology has become a regular occurrence. Not only linguists, but also specialists in various fields of science and technology, and even a whole team of scientists are engaged in word creation. This ensures the evolution of language, in particular, the dynamics of the terminology of different disciplines.

\section{REFERENCES}

1. L.S. Abezgauz. (1965) On the question of terminological synonymy. - In the book: Questions of general and RomanoGermanic linguistics: Abstracts. Report Ufa. No. 2, - pp. 13-16. (Абезгауз Л.С. K вопросу О терминологической синонимике.- В кн.: Вопросы общего и романо-германского языкознания: Тез. докл. Уфа, 1965, вып. 2, с. 13-16.)
2. Akulenko V.V. (1974) Scientific and technical revolution and the problem of international terminology. - In the book: Scientific and technical revolution and the functioning of the languages of the world. - Moscow. - pp. 50-52. (Акуленко В. В. Научно-техническая революция и проблема интернациональной терминологии. - В кн.: Научнотехническая революция и функционирование языков мира. М., 1974, с.50-52.)

3. Alaverdova L. G. (1961) Development of synonymous relations between substantivized adjectives with nouns of the same root in French. - Account of Leningrad State University, series Doctor of Philology. 283, Issue 56, - pp.12-51. (Алавердова Л. Г. Развитие синонимических отношений между субстантивированными

прилагательными с существительными того же корня во французском языке . Уч. зап. ЛГУ, серия филол. наук, 1961, т.283, вып.56, с.12-51.)

4. Kostitch A. Le problème de la terminologie médicale. - La Presse médicale, 1971, N1, p.20.

5. Kostitch A. Les problèmes de la terminologie médicale internationale. - La Presse médicale, 1966, N28, p.1499.

6. Rasuljanovna, I. N. (2020). The concept of "lacuna" in translation studies. Asian Journal of Multidimensional Research (AJMR), 9(4), 123-129. 

(ISSN - 2689-100x)

Published: May 31, 2021 | Pages: 172-174 